ADDIN, Volume 11, Number 2, August 2017

\title{
UMER CHAPRA CONTRIBUTION IN BUILDING MUSLIM CIVILIZATION
}

\author{
Umma Farida \\ STAIN Kudus, Central Java, Indonesia \\ mafarahman@gmail.com
}

\begin{abstract}
The idea of Umer Chapra in building Muslim civilization was based on his research on the position of Muslims who from time to time more and more felt strange with the civilization and Islamic values itself, even the civilization was gradually increasingly eroded and marginalized by Western culture. He tried to restore the Muslim position which should be done as the Messenger of Allah had pointed out, and their positive role in building civilization. The Islamic civilization has the power that lies in the development of morals and material strength. For Chapra, the moral development without being integrated with the economic development cannot be realized. And at the same time, this economic development must also have a worldview and strategy that is in line with religious objectives (maqashid asy-shariah). The development of Muslim civilization requires the transformation of human beings and their institutions, focusing in the increasing of education andpersonality development, and the simultaneous mobilization of material, economic and technological resources for the rearrangement of community structures over the principles of deliberation and accountability, unity, independence and justice.
\end{abstract}

Keywords: Islam, Civilization, Development, Moral, Justice. 
Abstrak

KONTRIBUSI UMER CHAPRA DALAM MEMBANGUN PERADABAN MUSLIM. Gagasan Umer Chapra dalam membangun peradaban Muslim berdasarkan pada penelitiannya tentang posisi umat Islam dari waktu ke waktu semakin terasa aneh dengan peradaban dan nilai-nilai Islam itu sendiri. Babkan, peradabannya juga semakin terkikis dan terpinggirkan oleh budaya Barat. Ia mencoba mengembalikan posisi Muslim seperti yang Rasulullah saw. tunjukkan dan peran positif mereka dalam membangun peradaban. Peradaban Islam memiliki kekuatan yang terletak pada pengembangan moral dan kekuatan material. Bagi Chapra, perkembangan moral tanpa diintegrasikan dengan pembangunan ekonomi tidak dapat direalisasikan. Dan, pada saat bersamaan, pembangunan ekonomi ini juga harus memiliki pandangan dunia dan strategi yang sejalan dengan tujuan keagamaan (maqashid asy-syariab). Perkembangan peradaban Muslim membutubkan transformasi manusia dan institusinya dengan fokus pada peningkatan perkembangan pendidikan dan kepribadian, serta mobilisasi sumber daya material, ekonomi, dan teknologi secara simultan untuk penataan kembali struktur masyarakat berdasarkan prinsip pertimbangan dan akuntabilitas, persatuan, kemerdekaan, dan keadilan.

Kata Kunci: Islam, Peradaban, Perkembangan, Moral, Keadilan.

\section{A. Introduction}

The superiority of civilizations that Muslims have built in the past is hard to lose from the memory of every Muslim. The enchantment of civilization based on the faith and values of Islam continues to motivate them to revive the civilization.

Islam as a universal religion has been empirically proven that it is the most widely encompassing religion of various races and nations, with an area of influence covering 
almost all climatological and geographical features ${ }^{1}$. Every time Islam enters a country it will create a civilization within the country. The reference sources in the formation of this Muslim civilization are the Qur'an and Hadith that serves as a unifying force that is not owned by other civilizations.

Gustave E. Von Grunebaum with a wonder tone once wrote in his paper, Pluralism in the Islamic World, as quoted by Hamid Fahmy Zarkasyi as follows:

"Nations come and go. The kingdoms rise and fall. But Islam persists and can safeguard travelers (nomads) and settlers, builders of civilizations in Islam and their destructors. So what factors unite them into one umma; Those who are conscious or unprepared to maintain their individuality, while on the other hand endeavor to bind themselves to universal Islam as their precious spiritual wealth." ${ }^{2}$

However, the present reality tends to show the decline of Muslim civilization, with indicators of the absence of accountability of power holders and good governance, moral degradation, and the inefficient and unjust economic systems. They are perceived as failing to learn from the gloriousness of civilizations that had been built in the past. This prompted many Muslim intellectuals, including Umer Chapra, to reformulate the factors that support the development of their civilization.

${ }^{1}$ Nurcholis Madjid, Islam Doktrin dan Peradaban: Sebuab Telaah Kritis Tentang Masalab Keimanan, Kemanusiaan, dan Kemodernan, Jakarta: Paramadina, 2000), 426.

${ }^{2}$ Hamid Fahmi Zarkasyi, "Ikhtiar Membangun Kembali Peradaban Islam yang Bermartabat", in Laode M. Kamaluddin (ed.), On Islamic Civilization: Menyalakan Kembali Lentera Peradaban Islam yang Sempat Padam, (Semarang: Unissula Press, 2010), 42. 


\section{B. Discussion}

\section{Biography of Umer Chapra}

During this time, Umer Chapra was known to the public as an economic expert, though his idea to rebuild Islamic civilization cannot be underestimated. This original Pakistani figure who later settled and switched citizenship of Saudi Arabia was born on February 1, 1933. His father was Abdul Karim Chapra, a devout person, so that makes the daily life of his family cannot be separated from religious education. He got his Primary and secondary education in his hometown. His intelligence was apparent when he was in school which was shown by his model student title among 25,000 exam students in 1950. Then he continued his undergraduate studies to Karachi University to a BBA degree in 1954 and his master's degree in 1956. While his Ph.D. was achieved from the University of Minnesota in Islamic economics in $1961 .^{3}$

The experts who influence Chapra's thought are Maulana Abu al-A'la al-Maududi, the leader of Jama'ah Islamiyah organization, and Umar Chapra actively followed al-Maududi's studies. In fact, Chapra with some of his friends such as Zafar Ishaq Ansori, Khurshid Ahmad and others were active in the Islami Jamiat Talaba, an Islamic organization which is the wing of the student organization of the alMaududi-led organization.

Chapra's academic career was begun by being a lecturer at the University of Minnesotta (1957-1960), an associate professor at the University of Wisconsin, Platteville (19601961 and 1963-1964), a Senior Economist at the Institute of Economic Development, Karachi, Pakistan (1961-1962),

${ }^{3}$ Umer Chapra, Peradaban Muslim: Penyebab Keruntuban dan Perlunya Reformasi, (Jakarta: Amzah, 2010), viii. 
and an Assosiate Professor at the University of Kentucky, Lexington (1964-1965). In addition, Chapra was a member of the Saudi Arabian Monetary Agency for 34 years (19651999), and at the same time he was active in various studies. Then he became an advisor to the Islamic Research and Training Institute of the Islamic Development Bank of Jeddah. ${ }^{4}$

His preoccupations in academia did not prevent Chapra from being active in several scientific and organizational meetings. He was actively present at the International Monetary Fund (IMF), the International Bank of Reconstruction and Development (IBRD), the Organization of Petroleum Exporting Countries (OPEC), the Islamic Development Bank (IDB), and the Organization of the Islamic Cooperation (OIC).

Chapra's expertise in economics is recognized internationally, as proven by the many requests for Chapra to be a guest lecturer providing lectures or scientific presentations at several universities in many countries such as England, Japan, Bangladesh, Egypt, Turkey, Spain, South Africa, United Arab Emirates, Morocco, Kuwait, Malaysia, Jordan, the United States, India, and Germany.

In addition, Chapra was a very productive writer with 12 books, 75 scientific papers, and 9 book reviews. Among his works are: Toward a Just Monetary System (1985), Islamic Monetary System (1985), Islam and Economic Challenge (1992), Islam and the Economic Development (1994), The Future of Economics: an Islamic Perspective (2000).

The articles written by Umer Chapra are: The Probibition of Riba in Islam: An Evaluation of Some Objections (1984), The Need for a New Economic System (1991), Islam and the International Debt Problem (1992), The Role of Islamic Banks in Non-Muslims

${ }^{4}$ Umer Chapra, Reformasi Ekonomi: Sebuah Solusi Perspektif Islam, trans. Ikhwan Abidin Basri, (Jakarta: Bumi Aksara, 2008), vii. 
Countries (1992). Many of his work were translated into Arabic, French, German, Japanese, Urdu, Persian, Turkish, Spanish, Polish, including Indonesia.

Due to his numerous works, and his great interest in the development of Islamic economics and his devotion to propagation of Islam, he received an award from the Islamic Development Bank and from the King Faisal International Award in 1989.

\section{Islam Religion of Civilization}

Islam as a religion that was born in Mecca by emphasizing on the transcendental unity of God (tawhid) expressly gives identity to the civilization it built. Islam has played an important role that sparked the progress of the Muslim community. Islam activates all development factors in a positive direction. Islam gives maximum strength to the human aspect, which is the primary force behind the fall and wake of civilization of a society. Islam seeks its adherents as more qualified human beings, and seeks to reform all the institutions that surround them. Or in other words, Islam seeks to elevate mankind morally and materially, creating a balance between material and spiritual aspects, seeing that both are important factors for the development of human quality and well-being.

Not only that, Islam also provides the sacredness of the meaning of life, the honor of the individual and the property, and gives a high degree of knowledge $\mathrm{e}^{5}$, by making the first verse revealed to the messenger of Allah in the form of the urgency of science. ${ }^{6}$ Islam gives women a respectable position and orders men to treat them well. ${ }^{7}$ Islam places

\footnotetext{
${ }^{5}$ Q.S. al-Mujadilah [58]: 11.

${ }^{6}$ Q.S. al-Alaq [96]: 3-5.

${ }^{7}$ Q.S. an-Nisa' [4]: 19.
} 
education and proper coaching for children as an important goal of shari'a, to ensure that future generations are able to bear the burden of subsequent development. ${ }^{8}$

The revolutionary Islamic world view has changed the philosophy of human life by injecting a meaning and purpose in life. Islam makes human beings parallel in its position as caliph on earth. Islam provides justice, dignity, equality to all mankind without distinction of sex, race, position and wealth. Islam makes this ideal as an effective reality by forming a leadership over the weak and oppressed. ${ }^{9}$

It is this noble ideals in Islam that inspire Chapra to rebuild Muslim civilization, which cannot be separated from its main teachings, namely the Qur'an and Sunnah. For him, an important factor in building Muslim civilization is to adhere to the teachings of Islam itself, with two main sources of comprehensive power in regulating human affairs and its transformation. Chapra's opinion is based on the statement of the Qur'an itself that God will not change the state of a people until they change their own circumstances. ${ }^{10}$ Both verses above assert that the real man became the architect of his own destiny. Man is not only a final goal, but also a means of development. Even in the Q.S. an-Najm [53]: 39 , it mentions that humans will not get in addition to what they earn. Thus, the advancement and retreat of human civilization can only be explained rationally by analyzing their own motivations, efforts, character and personality.

The Qur'an has undertaken a great revolution with its preference to the weak and oppressed. This is understandable given the history of the Qur'an itself the history of salvation and liberation for humanity. The Qur'an is revealed to save

\footnotetext{
${ }^{8}$ Chapra, Peradaban Muslim, 49.

${ }^{9}$ Q.S. asy-Syu'ara' [26]: 56.

${ }^{10}$ Q.S. ar-Ra'd [13]: 11 and Q.S. al-Anfal [8]: 33.
} 
and liberate man from all forms of moral, social, cultural, and structural oppression, both in the form of ideas and in the form of its praxis.

This rescue and liberation mission takes place through 2 (two) paths namely vertical and horizontal path. On the vertical path, the Qur'an as the word of God conveyed to the Prophet Muhammad immediately responds to the actual problems that occur in society. The horizontal path-after the Prophet's death and composed into the Mushaf of the Qur'an through interpretations are dialogued with the reality of life so that it can give birth to salvation, liberation and enlightenment over all universal humanity issues. ${ }^{11}$

Chapra's conviction to be able to rebuild Islamic civilization as well as the past is also because Islam is the only reality living in a Muslim world that has the charisma to attract the masses, unite them in spite of them, and motivate them to do the truth even if they are degraded. Islam provides a balanced and workable program for comprehensive political, economic, social and moral reforms. In fact, the Islamic emphasis on social-economic justice, the accountability of political authority, and the character of development in instilling education and dialogue to create a change can prove to be a great gift to the Muslim world. Simple teachings in Islam that reduce the pattern of consumption of exhibition can weaken one cause of corruption.

Islam can also internalize in a person a variety of noble qualities that are needed, such as integrity and honesty, keeping promises, working hard, self-confident, empathizing with the rights and welfare of others, without these qualities efficiency and justice are difficult to achieve. Islam positions social solidarity and family harmony as important for the

${ }^{11}$ Hendar Riyadi, Tafsir Emansipatoris: Arah Baru Studi Tafsir Al-Qur'an, (Bandung: Pustaka Setia, 2005), 70-73. 
survival of a society. Shortly, Islam is flexible enough to adapt to changing and evolving circumstances. ${ }^{12}$

\section{Building Muslim Civilization according to Umer Chapra}

The idea of Umer Chapra in building Muslim civilization was based on his research on the position of Muslims who from time to time feel more and more strange to the civilization and Islamic values itself, even civilization gradually increasingly eroded and marginalized by Western culture. He tried to restore the proper position of the Muslims as the Messenger of God had pointed out, and their positive role in building civilization, although he himself realized that this was an uneasy colossal work.

Chapra's hope is strengthened by binding on the statement of the Qur'an in the Q.S. Ali Imran [3]: 110 that Muslims are the best people presented to man. Thus, this people should make a positive contribution in building world civilization. ${ }^{13}$

For Chapra, history is not only a series of events, but more than that it is a collection of images that reveal a series of achievements and failures, brilliance and misfortune, and glory and destruction. History is also a record of the long journey of mankind to tomorrow, the collection of the past to this day, and the gatekeeper to meet the future. It is like a mirror by which man can understand the fall episode and the rise of a nation and civilization through the interrelationship of ideas, individuals, institutions, and society. In addition, history also offers mankind a space to learn from the past, pursue today, and welcome a better future. With history, the human eye is wide-eyed, and thought is confronted with a

${ }^{12}$ Chapra, Peradaban Muslim, 242-243.

${ }^{13}$ Ibid., xii-xiii. 
series of challenges. The challenge of responding, analyzing, and digging deeper is the cause behind the event. ${ }^{14}$

The inspiration for building Muslim civilization-in Chapra's view-comes from Islam itself. This is because the vision of Islam is built on a society where the individuals in it are shrouded in morals and intertwined together through strong fraternal ties, where justice prevails and all needs are met, the whole family becomes strong and the children get love, love and concern for both parents, where crime and tension can be minimized and social justice prevails. ${ }^{15}$

Chapra confirms that the foundation of faith is the factor that distinguishes Islamic civilization from other civilizations, with its main characteristics that combine spiritual and material, moral and mundane aspects. He views life as a whole organ. Therefore, all the problems faced in this life must be broken down through a holistic and comprehensive approach, not through a partial and separate approach to one another. ${ }^{16}$

Humans as dynamic beings have the motivation to gain a good life and build their civilization. One of the things that affect this motivation is the effort they do in improving the welfare. It is hoped that community development will bring positive impacts to the realization of the equitable distribution of development products to all levels of society, regardless of color, sex, age, position, wealth and religion. ${ }^{17}$

Building civilization requires a productive and moral human resources. It is not proper that human energy is wasted only for conflict and warfare, but human energy is empowered for the improvement of moral, physical, and
${ }^{14}$ Ibid., xv.
${ }^{15}$ Ibid., 64.
${ }^{16}$ Ibid., xx.
${ }^{17}$ Ibid., 6. 
intellectual qualities, by making justice an important factor in building a dignified civilization. The importance of justice as a pillar of this civilization has been stated in the Q.S. Thaha [20]: 111. The absence of justice precisely makes civilization stagnant and undeveloped, it may even lead to decline, because with injustice in development will trigger disharmony and conflict.

Justice in building human civilization will be realized if accompanied by social agreements, institutions or rules of behavior that can be accepted and obeyed consistently by everyone. This agreement includes respect for the soul (right to life), belief or religion, and property. Everyone should promote honesty and integrity, passion for hard work, and caring for those in need. To realize people who are moral and motivated to continue to learn and work hard certainly cannot be separated from the role of the family. ${ }^{18}$ Thus, building a moral Muslim civilization starts from education in the family.

Chapra's views on the importance of education in the family are in line with Ibn Khaldun's statement that the sign of civilization is the development of science such as physics, chemistry, geometry, arithmetic, astronomy, medicine and so on. In fact, the rise and fall of a civilization related to the advancement of science. ${ }^{19}$ The importance of education is also expressed by Imam asy-Syaibani in Ahmad Izzan that in fact every individual has a very open, flexible, able to be formed and changed. The flexibility of a person's character in terms of physiological, is the result of the nature of nerve tissue and brain cells. Nerve flexibility is influenced by the process of habituation and practice continuously. In addition, the environment is also believed to have a major influence on

${ }^{18}$ Ibid., 8.

${ }^{19}$ Ibn Khaldun, Muqaddimah, (Cairo: Maktabah Wahbah, 1997), 54-57. 
the moral formation of a person. These environmental factors include the family, school, and community environment. ${ }^{20}$

Essentially, education is an attempt to foster the personality of each individual to be better in accordance with the rules of religion and norms that exist in society. In the family environment, every adult-in this case-the parent will inevitably have to play a role as, because the educator is a fundamental social act for the growth or development of the next generation to be a good and wise man. Or in other words, the parent is the first educator in which the child interacts from birth, grows, and develops. The family is also the oldest and most important educational institution, since most of the child's life is in the midst of the family, so the most widely accepted educational process also comes from the family. Hence, known in the Arabian proverb, al-ummu madrasatun (Mother is school).

Education in the family is not a theoretical course, but many are practical, by sharpening skills and realizing a democratic atmosphere. Each member of the family freely expresses, works, and argues, and is trained to be tolerant and respect the opinions and works of others.

If the family fails to perform its role as an educational institution for its members, it will be more difficult for its recovery efforts. The failure of education in the familyaccording to Chapra-can occur at least for two reasons: First, if in the family, parents do not have the personal qualities that enable them to educate their children. Second, if in the family there is no nuance of love and attention, caring and caring each other. ${ }^{21}$

${ }^{20}$ Ahmad Izzan and Saehudin, Tafsir Pendidikan: Studi Ayat-ayat Berdimensi Pendidikan, (Banten: Pustaka Aufa, 2012), 103.

${ }^{21}$ Chapra, Peradaban Muslim, 9. 
In addition to the family, existing institutions in society also have a role in building a moral civilization. Only fair institutions are capable of realizing civilization. The principle of fairness is to fulfill the rights and obligations according to their respective capacities, without coercion. Therefore, a standard is required of how humans should interact and carry out the obligations. In this case, institutions in Muslim societies must establish standards of rules of conduct based on religious norms (shari'a), since the true existence of sharia is for the good of humanity and the interests of society. Shari'a teaches to do good and avoid bad and destructive actions.

However, Chapra realizes that not all countries where Muslims live have based their institutional norms on the rules of shari'a that resulted in the Shari'a not playing a maximum role in building the civilization of Muslim society. Whereas "Good governance", which is the jargon of almost all countries that gives recognition of individual ownership and individual respect in the framework of moral values, is in fact a part of Islamic teachings and will always be in harmony with Muslim thought.

Referring to Ibn Khaldun's opinion, Chapra revealed that institutions in society should be able to play a role in protecting and ensuring the safety of the people, maintaining laws and regulations, ensuring justice, striving for the fulfillment of life, eliminating public woes and improving their welfare. ${ }^{22}$

Islamic civilization has the power that lies in the development of morals and material strength. For Chapra, moral development without integration with economic development cannot be realized. This is because the

\footnotetext{
${ }^{22}$ Ibid., 32.
} 
development of science and technology go hand in hand with increased savings and investment that can accelerate the development process. And at the same time, this economic development must also have a worldview and strategy that is in line with religious objectives (maqashid asy-shari'ab). ${ }^{23}$

In addition, economic development must also consider the principles of efficiency and justice that are not only accountable to fellow human beings, but also to God. Therefore, Chapra emphasizes that in economic development it is necessary to utilize all the potential of human and material resources along with all its components such as market, monetary and financial system, public and private sectors. Thus, it is expected that the quantity of goods and services produced can be maximally successful. Every individual also has equal opportunity to work and produce, and manage his income efficiently as well.

The role of the state in this economic development cannot be underestimated. The state is obliged to eradicate poverty, maintain the stability of the real value of money, create full employment conditions, uphold moral values, provide legal certainty and create order, ensure social and economic justice, establish social security and promote equitable distribution of income and wealth, to public financial resources and expenditures, and harmonize international relations and safeguard state defense.

Disregarding economic development, it is feared to lead to fiscal imbalances, rampant corruption, unjust distribution of wealth, tax delays, declining currency values, which lead to economic crisis and state dependence on foreign loans. ${ }^{24}$

\footnotetext{
${ }^{23}$ Umer Chapra, Masa Depan Ilmu Ekonomi: Sebuah Tinjauan Islam, (Jakarta: Gema Insani Press, 2001), 151-153.

${ }^{24}$ Umer Chapra, Sistem Moneter Islam, (Jakarta: Gema Insani Press, 2000), $90-97$.
} 
In addition to economic factors, the construction of Muslim civilization also requires the transformation of human beings and their institutions, which is accompanied by the motivation of spiritual power and united in fraternal bonds. Unity among individuals makes it possible to create a good, stable, and strong government. This is evidenced by the Prophet Saw himself when establishing the state of Medina. The tribes that have for centuries been engaged in disputes can be united in a brotherhood which is able to bring about an honest government, an orderly life and a guaranteed security, and the establishment of an orderly and fair market, which further encourages the realization of development in all fields.

The demographic sector of the progress of rural and urban societies with economic growth in these two regions also serves as a catalyst for development. The transformation of prosperity from one sector to another over time has formed one of the most important foundations in socio-economic and political dynamics and fosters intellectual progress.

\section{Anticipating Causes of Civilization Degradation}

Like most Muslim scholars, Chapra also holds that the cause of the weakening of the strength of Islamic civilization is not because of Islam itself. Chapra vigorously refutes the opinion of orientalists who say Islam is the trigger of civilization's decline, and leads to poverty and backwardness in society. He reversed orientalist arguments such as Marcus Noland $^{25}$ and Timur Kuran ${ }^{26}$ which mentions the existence

${ }^{25}$ Marcus Noland, "Religion, Culture, and Economic Performance", https://papers.ssrn.com/sol3/papers.cfm?abstract_id=472484, downloaded 21/05/2017.

${ }^{26}$ Timur Kuran, "Islam and Underdevelopment: an Old Puzzle Revisited", Journal of Institutional and Theoretical Economics, March 1997, http:// public.econ.duke.edu/ tk43/abstracts/articles/ar_31A.pdf, downloaded 21/05/2017. 
of three Islamic institutions which actually hinder the development, namely: (a) The system of equality inheritance in Islam that does not justify the primogeniture system deeply rooted in Islamic society; (b) The absence of the concept of limited liability and the specificity of laws or laws in Islam; (c) Waqf institutions.

Chapra explained that the absence of primogeniture system in the concept of inheritance in Islam because primogeniture in general only used to fulfill the will of feudalism. If primogeniture were assumed to play a role in European and American development then it would not be an excuse to assume that primogeniture is indispensable to nation-wide development. Because in fact the most important role in development in the world of Europe and America is good governance, land reform, social equality, and cultural values. ${ }^{27}$ In fact, the absence of primogeniture should have a financing effect for the formation of a business entity by motivating people to jointly put their capital as stock to form a larger and real business entity.

As for the absence of limited liability in the concept of Islamic economy as stated by Kuran, Chapra denied by explaining that the seed of the limited liability concept is actually already in the study of Islamic figh. The closest estimates of the corporate legal entity in Islam are bait almal (state treasurer), mosque, and waqf. Even the concept of limited liability that exists in the mudarabah (commenda) contract on the business organization has progressed considerably without the significant constraints that many corporations face in modern times. ${ }^{28}$

${ }^{27}$ Chapra, Islam dan Tantangan Ekonomi, (Surabaya: Risalah Gusti, 1999), 172-181; Chapra, Peradaban Muslim, 72.

${ }^{28}$ Chapra, Sistem Moneter Islam, 78. 
While related to the institution of endowments which Kuran viewed as a cause of the decline of Muslim civilization, Chapra responded that if the waqfinstitutions are managed according to Islamic rules and properly supervised then will make the progress of civilization and development. As for the reality that much happening now that the wagf institutions are not well managed, then the fault lies in the management system, not the institution of waqfitself, because conceptually waqf actually motivates society empowerment, social development, and physical infrastructure through individual generosity. So it has become the duty of the state to encourage the management of wagf according to Islamic principles.

If neither of the above mentioned topics by the orientalists is the cause of the Muslim civilization's retreat, Chapra then reveals 4 (four) factors causing the decline:

First, moral damage begins from the neglection of the role of the family in care and education. Because after all, every human being needs the proper education and legal, political and social institutions that ensure justice, the development of all human potential, and their participation in community development. Moral damage actually resulted in the death of creativity, vitality, and solidarity.

Second, the tyrant. Absolute power which is not accompanied by adequate accountability, neglect the democracy and the Islamic political system. In Chapra's view, every ruler actually has a responsibility to uphold a just state of justice and fulfill the demands of the people's welfare by regulating the state's affairs in accordance with the teachings of sharia and decisions on the basis of deliberation. Government leaders should be elected by the people free and secret, and avoid money politics. Although leaders are elected and accountable to the people, but both-leaders and 
people-have no absolute freedom in the Khilafah system. Both are contractually bound to the objectives, moral limits, and institutions of sharia. ${ }^{29}$

Chapra added that even today the Islamic world has not been able to re-establish a procedure that has been exemplified by Muhammad saw. in organizing the government in Medina, which can unite Muslims, ushering in a regular and peaceful transfer of power which enables a competent and respected person to be elected, the realization of the use of a just and efficient public resource in accordance with shari'a, and the presence of free criticism without being covered fear of government policies. The frequent fact is that military power-taking through coups or hereditary successions still prevails in the majority of Muslim countries. ${ }^{30}$

Third, stagnation and declining quality of education. The important contributions of Muslims in the past in the fields of research, science and technology need to be revived. This is manifested by the formal support of the government apparatus in creating a conducive scientific tradition that is amazing in various educational activities as happened in the early period of the Islamic world. Muslims at that time did not only make use of the intellectual contributions that Greek, Persian, and Indian civilizations had provided but they also enriched and developed their own scientific traditions in various fields of science such as physics, mathematics, astronomy, biology, chemistry and medicine. Therefore, it is not surprising that the contribution of Muslims continues to be remembered for four centuries (since the age of VIII-XII).

The scientific tradition as described above has now shifted toward stagnation due to the declining financial

\footnotetext{
${ }^{29}$ Chapra, Peradaban Muslim, 81.

${ }^{30}$ Ibid., 81.
} 
support of the state to improve the quality of education and the imposition of certain thoughts that silence the creative thinking and expression. In fact, according to Chapra, the factor that exacerbated the decline of science and technology in some parts of the Islamic world is the conflict that arises between rationalists and conservatives as a result of the use of the power of the state by the rationalists to carry out his views that often get resistance from the people. The debate between the Mu'tazilah and the philosophers confronting Ablussunnah wal Jama'ah is an example of endless tensions to this day. Similarly, the inquisition (mihnah) that had been experienced by the classical scholars became the trigger of intellectual stagnation in the Islamic world. ${ }^{31}$

Fourth, disharmony of public relations and government. The history of the Islamic world proves the tidal relationship between the two. Whereas a harmonious relationship will create a conducive atmosphere in the application of religious norms, ensuring the implementation realization of the Law and social institutions, and building a just civilization. ${ }^{32}$

The disharmony of public relations and government also affects their attitude towards women. The position of respectable women in the time of the Prophet. as taught in the Qur'an they no longer notice. ${ }^{33}$ In fact, women are the pillars of civilization. The Qur'an asserts the equal rights of men and women ${ }^{34}$ The Qur'an also demands men to treat them well, ${ }^{35}$ and fulfill their duty to them with affection. ${ }^{36}$

In early Islam, women also participated in various religious, social, educational, political, economic, and even

\footnotetext{
${ }^{31}$ Ibid., 138-166.

${ }^{32}$ Ibid., 179-182.

${ }^{33}$ Ibid., 193.

${ }^{34}$ Q.S. al-Baqarah [2]: 228.

${ }^{35}$ Q.S. an-Nisa' [4]: 19.

${ }^{36}$ Q.S. al-Baqarah [2]: 237.
} 
war activities. Ruth Roded recorded that 1551 female companions (sahabiyyat) doing scientific activities by collecting and teaching the hadiths of the Prophet. ${ }^{37}$ But this decline tends to decrease along with the generation overturn. This reduction in numbers is often attributed to the typical position of female companions as a precedent and an early model of women's role in Islamic societies that are different from those of women after the time of the Prophet. Political and cultural factors that tend to marginalize women also contributed to the decline of women's role in various other scientific and social activities.

Abdul Djamil also revealed that there is actually a contradiction between moslem scholars after the death of Prophet saw. with the social reality of his time. In fact, in the time of the Prophet saw. women occupy strategic posts in intellectual, economic, and even political life. This is reinforced by a historical record that describes the various involvements of women in jihad, caring for victims, and others. This diverse position certainly signals that women interact with men in their daily activities. ${ }^{38}$

Therefore, the resurrection strategy to build the Muslim civilization as well as to anticipate the decline of civilization, is focused on improving education and personality development, and mobilization of material, economic, and technological resources simultaneously for the restructuring of society structures over the principles of deliberation and accountability, unity, independence, and justice.

The above strategy needs to be supported by 4 (four) things, namely: (a) proper coaching and moral education,

${ }^{37}$ Ruth Roded, Kembang Peradaban: Citra Wanita di Mata Para Penulis Biografi Muslim, (Bandung: Mizan, 1995), 18.

${ }^{38}$ Abdul Djamil, "Kata Pengantar", in Sri Suhandjati Sukri, Bias Jender dalam Pemahaman Islam, (Yogyakarta: Gama Media, 2002), xiv-xv. 
especially for the younger generation, combined with the necessary skills training; (b) justice, law and order, and the security of life, property and honor of each individual; (c) decent work and job and striving opportunities that enable everyone to channel their talents to improve the well-being of themselves and their communities; (d) an environment conducive to hard work and creativity, as well as to build mutual trust, cooperation, and social solidarity. ${ }^{39}$

Chapra added that these conditions will be difficult to fulfill without proper worldview. This is because the worldview is closely related conceptually to all human activities socially, intellectually, and religiously. Worldview according to Sayyid Qutb is the accumulation of the basic beliefs that are formed in the minds and hearts of every Muslim, which gives a special picture of the existence and whatever is behind the existence. ${ }^{40}$

The worldview as a system of belief, ideas, thought, and values has the power to change. Furthermore, it is worldview that provides values or rules of conduct that explain in detail the rights and responsibilities of all members of society. These values will in turn be useless without accompanying a comprehensive implementation for the shared welfare of a strong and efficient and accountable government to the people. While individual moral reforms are absolutely necessary, increasing the wealth of society is equally important, not only to improve the welfare of the people so that they are motivated to do their best, but also to provide resources to the government to be able to fulfill its obligations effectively. ${ }^{41}$

\footnotetext{
${ }^{39}$ Chapra, Peradaban Muslim, 200.

${ }^{40}$ Sayyid Qutb, Maqumat at-Tadammur al-Islami, (Cairo: Dar asy-Syuruq, 1998), 41.

${ }^{41}$ Chapra, Peradaban Muslim, 200.
} 


\section{Analysis of Chapra's Thought in Building Civilization}

It is undeniable that there are many ideas of characters influencing Chapra's thinking. A series of prominent figures who have studied the fall and wake of a civilization such as Ibn Khaldun (d. 808/1406) and Gibon (d. 1208/1794) in the past, and Spengler (1947), Schweitzar (1949), Sorokin (1951), Toynbee (1957), North (1973), Kennedy (1987) have enriched Chapra's insights. Nevertheless, Ibn Khaldun's idea was the most influential of all these thinkers' ideas, accompanied by an adaptation to the contemporary reality of the model of civilization development by Ibn Khaldun that had been formulated since 600 years ago in his Muqaddimah.

Ibn Khaldun's theory of development and setbacks that inspired Chapra are summarized in eight principles. First, the power of sovereignty (al-mulk) cannot be maintained unless by implementing religious norms and rules of conduct (shari'a). Secondly, the Shari'a will not be implemented unless it is a sovereign (al-mulk). Third, sovereignty will not gain strength unless supported by human resources. Fourth, human resources cannot be maintained except with property. Fifth, property cannot be obtained except by development. Sixth, development cannot be achieved except with justice. Seventh, Justice is the benchmark that God uses to evaluate people. Eighth, sovereignty has a responsibility to uphold justice. ${ }^{42}$

For Chapra, the strength of Ibn Khaldun's model above lies in his cross-disciplinary and dynamic character. Cross-discipline is because it connects all socio-economic and political variables, including government and political authority, beliefs and rules of conduct, people, property

\footnotetext{
${ }^{42}$ Ibn Khaldun, Muqaddimah, 39.
} 
and resource reserves, development, and justice in an interindependent spin of influence. ${ }^{43}$

Although Ibn Khaldun's thought dominantly influenced Chapra in attempting to build Muslim civilization, there was a distinction between the two minds that the building of civilization in Ibn Khaldun's model was not always synonymous with economic development. Ibn Khaldun considers the state not to be directly involved in economic activity, because it will hinder the people's opportunity to gain profit, disrupt the private sector, and even lower state revenues from the tax sector. While Chapra states that without economic development then the process of community development will not be realized.

Chapra's notion that beliefs are the distinguishing factor of Islamic civilization from other civilizations in line with Sayyid Qutb's opinion states that faith is the source of civilization, although in Islamic civilization the organizational structure and form are materially different, but its principles and values are one and permanent. These principles are piety, belief in the unity of God (tawhid), supremacy of humanity above all material things, the development of human values and guarding of animal desires, respect for the family, realizing its function as khalifah on earth based on guidance and His command. ${ }^{4}$

In line with Sayyid Qutb, Muhammad Abduh stressed that religion or belief is the principle of all civilizations. Ancient nations like Greece, Egypt, India, and others built their civilization from a religion, a belief, or a faith. Arnold Toynbee also acknowledged that spiritual power is a force that

${ }^{43}$ Chapra, Peradaban Muslim, 24-25.

${ }^{44}$ Hamid Fahmi Zarkasyi, "Ikhtiar Membangun Kembali Peradaban Islam”, 20. 
enables a person to give birth to the outward manifestation which is then called civilization. ${ }^{45}$

Ismail Raji al-Faruqi also considers the importance of the founder of Islam in building civilization. Specifically, alFaruqi positioned monotheism as the most basic principle that embraces and determines other principles, and binds the elements of science, culture and civilization as an integral and organic entity, then forming it in its own framework to harmonize and support each other. With the identity of monotheism that Islam attaches to the civilization, the rate of change can vary, from small to radical. Change is small if it only affects the shape, and radical if it affects its function. Therefore, in the view of al-Faruqi Muslims need to develop the science of monotheism and make the disciplines of logic, epistemology, metaphysics and ethics as its branches. ${ }^{46}$

Still according to al-Faruqi, holding on to the principle of monotheism is a necessity and is the foundation of all moral values, goodness, and religiosity. A Muslim can be defined by his obedience to monotheism, with his recognition of the unity and transcendence of God as the supreme principle of all existence, life, and cosmos. There is no provision in Islam that can be released from monotheism. Even the implementation of all religious teachings, either command or prohibition will be destroyed if it is against the monotheism. ${ }^{47}$

The urgency of education and technology for the development of civilization necessitates the elimination of the gap between the Muslim world and the developing countries by offering high quality education and research facilities through the development of schools and colleges.

\footnotetext{
${ }^{45}$ Ibid.

${ }^{46}$ Ismail Raji al-Faruqi, Taubid, (Bandung: Pustaka, 1988), 16-17.

${ }^{47}$ Ibid., 18-19.
} 
Education should be enjoyed by all levels of society, including the poor. In order to alleviate poverty, it is necessary to provide microfinance institutions for the poor, in order that they are able to realize the dream of owning their own businesses. At the same time, it is important to realize justice of the distribution of income and wealth, as well as to ensure social equality, brotherhood and mutual respect among the Muslim community. Therefore, justice, moral and socio-economic improvement, brotherhood, and reform of all institutions become interrelated, because it is impossible to build a sustainable civilization on one area without the development of other fields. ${ }^{48}$

Chapra's view that justice as a pillar of civilization is also aligned with the mission of the Qur'an which Fazlur Rahman calls "to create an ethical, egalitarian, and just social order". ${ }^{49}$ Therefore, humans as the driving force of civilization should pay attention to three main points of the Qur'anic guidance, namely: universal brotherhood, equality, and social justice.

Asghar Ali Engineer explains these three things as follows: First, fraternity. This brotherly doctrine implies that the whole human being is a sibling. The diversity of tribes, nations, languages, skin color is not to be discriminated against one another but rather to get to know each other. Differences in attitudes, ideas, positions, actions between one another are not aimed at triggering tension and conflict but rather to compete for the goodness. ${ }^{50}$

Second, equality. This doctrine of equality implies that man as a whole is equal whether in a social, political,

${ }^{48}$ Chapra, Peradaban Muslim, 224-226.

${ }^{49}$ Fazlur Rahman, Tema-tema Pokok Al-Qur'an, trans. Anas Mahyudin, (Bandung: Pustaka, 1993), 54-55.

${ }^{50}$ Q.S. al-Hujurat [49]: 13 and Q.S. al-Ma'idah [5]: 48. 
or religious outlook. Therefore every human being should receive attention, equal treatment both in obtaining legal justice, get the opportunity to work, educated, and in the fulfillment of other human needs. Both men and women will get results in accordance with what he has cultivated. ${ }^{51}$

Third, justice. The meaning of justice is to treat equally or not to distinguish between one and another. ${ }^{52}$ In some places, the Qur'an commands to be fair to every group, whether to oneself, family, relatives, or society. Even the Qur'an ${ }^{53}$ also commands to be fair to the enemy and not to make hatred a barrier to justice. ${ }^{54}$

\section{Conclusion}

The Muslim civilization development model is uniqueaccording to Chapra-compared to other scholars, by including the economy with all its components such as markets, monetary and financial systems, the public and private sectors into the focus of the realization of efficiency and fairness in the use of resources, human aspect, but also all institutions that influence the development of civilization.

The resurrection strategy for building Muslim civilization focused on the re-understanding of the vision and mission of the people, the improvement of education and personality development, and the mobilization of material, economic, and technological resources simultaneously for the realignment of community structures above the principles of deliberation and accountability, unity, independence, and justice.

${ }^{51}$ Q.S. an-Nisa' [4]: 32.

${ }^{52}$ Q.S. an-Nisa' [4]: 58.

${ }^{53}$ Q.S. an-Nisa' [4]: 135 and Q.S. al-Ma'idah [5]: 8.

${ }^{54}$ Asghar Ali Enggineer, Islam dan Teologi Pembebasan, trans. Agung Prihantoro, (Yogyakarta: Pustaka Pelajar, 2000), 33. 


\section{REFERENCES}

Chapra, M. Umer. Islam dan Tantangan Ekonomi. Surabaya: Risalah Gusti, 1999.

- Masa Depan Ilmu Ekonomi: Sebuab Tinjauan Islam. Jakarta: Gema Insani Press, 2001.

- Peradaban Muslim: Penyebab Keruntuban dan Perlunya Reformasi. Jakarta: Amzah, 2010.

- Reformasi Ekonomi: Sebuah Solusi Perspektif Islam, trans. Ikhwan Abidin Basri. Jakarta: Bumi Aksara, 2008.

. Sistem Moneter Islam. Jakarta: Gema Insani Press, 2000.

Enggineer, Asghar Ali. Islam dan Teologi Pembebasan, trans. Agung Prihantoro. Yogyakarta: Pustaka Pelajar, 2000. al-Faruqi, Ismail Raji. Taubid. Bandung: Pustaka, 1988.

Ibn Khaldun, Abdurrahman ibn Muhammad. Muqaddimah. Cairo: Maktabah Wahbah, 1997.

Izzan, Ahmad and Saehudin. Tafsir Pendidikan: Studi Ayat-ayat Berdimensi Pendidikan. Banten: Pustaka Aufa, 2012.

Kamaluddin, Laode M. (ed.). On Islamic Civilization: Menyalakan Kembali Lentera Peradaban Islam yang Sempat Padam. Semarang: Unissula Press, 2010.

Kuran, Timur. "Islam and Underdevelopment: an Old Puzzle Revisited", Journal of Institutional and Theoretical Economics, March 1997, http://public.econ. duke.edu/ tk43/abstracts/articles/ar_31 A.pdf, downloaded 21/05/2017. 
Madjid, Nurcholish. Islam Doktrin dan Peradaban: Sebuah Telaah Kritis Tentang Masalab Keimanan, Kemanusiaan, dan Kemodernan. Jakarta: Paramadina, 2000.

Noland, Marcus. "Religion, Culture, and Economic Performance", https://papers.ssrn.com/sol3/papers. cfm?abstract_id=472484, downloaded 21/05/2017.

Qutb, Sayyid. Maqumat at-Tadawnur al-Islami. Cairo: Dar asySyuruq, 1998.

Rahman, Fazlur. Tema-tema Pokok al-Qur'an, trans. Anas Mahyudin. Bandung: Pustaka, 1993.

Riyadi, Hendar. Tafsir Emansipatoris: Arah Baru Studi Tafsir AlQur'an. Bandung: Pustaka Setia, 2005.

Roded, Ruth. Kembang Peradaban: Citra Wanita di Mata Para Penulis Biografi Muslim. Bandung: Mizan, 1995.

Sukri, Sri Suhandjati. Bias Jender dalam Pemahaman Islam. Yogyakarta: Gama Media, 2002. 